\title{
PEMBAHASAN HASIL PENELITIAN DALAM SKRIPSI MAHASISWA JURUSAN PENDIDIKAN BAHASA DAN SASTRA INDONESIA UNDIKSHA
}

\author{
${ }^{1}$ I Wayan Wendra, I Made Sutama ${ }^{2}$, Ni Made Wisudariani ${ }^{3}$ \\ 1,2,3 Jurusan Pendidikan Bahasa dan Sastra Indonesia, \\ Fakultas Bahasa Pendidikan dan Seni Universitas Pendidikan Ganesha \\ Singaraja, Indonesia \\ e-mail:wayan.wendra@ymail.com
}

\begin{abstract}
Abstrak
Penelitian ini bertujuan untuk: (1) mengetahui keberadaan unsur-unsur bagian pembahasan hasil penelitian dalam skripsi mahasiswa dan, (2) mengetahui unsurunsur yang luput pada penulisan pembahasan hasil penelitian dalam skripsi mahasiswa Jurusan Pendidikan Bahasa dan Sastra Indonesia. Rancangan penelitian ini adalah deskriptif kuantitatif dan kualitatif. Subjek penelitiannya pembahasan hasil penelitian dalam skripsi mahasiswa tahun terakhir. Objek penelitian adalah keberadaan unsur-unsur pembahasan hasil penelitian dan unsur-unsur yang luput dari penulisan bagian pembahasan. Penelitian ini menggunakan teknik sampel yang diambil secara random dengan jumlah sampel sebanyak delapan belas skripsi. Dengan demikian pengumpulan data dilakukan dengan metode studi dokumen dengan menggunakan instrumen format identifikasi unsur-unsur pembahasan. Data dianalisis secara deskriptif kuantitatif dan kualitatif. Hasil penelitian menunjukkan keberadaan unsur-unsur pembahasan hasil penelitian pada skripsi mahasiswa S1 Jurusan Pendidikan Bahasa dan Sastra Indonesia tidak ada yang lengkap dengan persentase kelengkapan $83 \%$. Unsur yang luput sama sekali dalam pembahasan hasil penelitian adalah unsur keterbatasan penelitian yang mempengaruhi generalisasi/hasil penelitian dengan persentase $17 \%$. Kalau dirinci bila ditinjau dari keberadaan perunsurnya sebagai berikut: (1) tinjauan tentang hasil-hasil penelitian yang penting sejumlah $100 \%,(2)$ pencermatan terhadap hasil yang mendukung/tidak hipótesis sejumlah 100\%, (3) Implikasi mengenai studi tentang teori terbaru sejumlah $100 \%$, (4) Saran-saran untuk penelitian lebih lanjut $83 \%$, (5) pertimbangan hasil penelitian ditinjau dari penelitian yang ada sejumlah $61 \%$, dan (6) keterbatasan penelitian yang mempengaruhi generalisasi/hasil penelitian sejumlah $0 \%$. Walaupun persentase kelengkapan unsur-unsur tergolong tinggi itu terbatas pada tinjauan keberadaannya atau ada tidaknya unsur-unsur. Namun dari segi kualitas penyajian pembahasan masing-masing unsur masih perlu ditingkatkan kualitasnya.
\end{abstract}

Kata kunci: pembahasan hasil penelitian skripsi mahasiswa 


\begin{abstract}
This study aims to: (1) determine the existence of the elements of the discussion sections in research and thesis students, (2) determine the elements that escape the discussion of writing student thesis research in Language and Literature Department of Education of Indonesia. The design of this research is descriptive quantitative and qualitative. Discussion of the results of his research subjects in the student thesis research last year. Object of study is the existence of the elements of the discussion and research elements that escape from writing the discussion section. In this study, using the technique of random samples taken with a sample size of eighteen thesis. Thus the data collection is done by the method of the study using an instrument format documents identifying the elements of the discussion. Data were analyzed by descriptive quantitative and qualitative. The results showed the existence of the elements of the discussion of the results of research on student thesis S1 Indonesian Language and Literature Education no complete with a $83 \%$ completion percentage. Elements which escape altogether the discussion of research results is an element of the study limitations that affect the generalizability/research results with the percentage of $17 \%$. If specified when viewed from the existence perunsurnya as follows : (1) a review of the results of the study are an important number of $100 \%$, (2) scrutiny of the results that support/hypothesis is not a $100 \%$, (3) the implications of the study for a number of theories $100 \%$, (4) Recommendations for further research $83 \%$, (5) consideration of the results of the study in terms of research that there are some $61 \%$, and (6) limitations that affect the generalizability of research/research a number of $0 \%$. Although the percentage of completeness of the elements is high it is limited to a review of its existence or presence or absence of the elements. But in terms of the quality of the presentation of each element of the discussion still needs to be improved.
\end{abstract}

Keywords : discussion of student thesis research

\section{PENDAHULUAN}

Kenyataan

menunjukkan,

hambatan sebagian besar mahasiswa dalam menyelesaikan studinya di perguruan tinggi di antaranya disebabkan oleh kesulitan menyusun karya ilmiah (skripsi, tesis, desertasi). Arifin (2006) menegaskan bahwa masalah penulisan karya ilmiah sebagai sumber kohesti (penimbunan permasalahan). Kenyataan yang tampak memang demikian adanya, masih banyak mahasiswa membutuhkan waktu panjang dalam menyelesaikan studinya karena dihambat oleh masalah penyelesaian karya ilmiah sebagai tugas akhir dalam menyelesaikan studinya.

Karena sadar akan adanya permasalahan tersebut, upaya bimbingan terhadap mahasiswa dan sasaran bimbingan oleh dosen pembimbing perlu agar terfokus pada permasalahan yang ada. Untuk itu diperlukan kajian terhadap permasalahan dalam menyusun skripsi dan bagaian-bagian mana yang bermasalah perlu dikaji secara pasti. Pada penelitian ini akan dikaji sub bagian pembahasan hasil penelitian yang berperan sangat penting dan sering bermasalah di kalangan siswa.

Jurnal Pendidikan Indonesia | 412 
Tulisan, termasuk tulisan ilmiah, yang memudahkan pemahaman pembaca memiliki tiga karakteristik. Pertama, tulisan itu harus memiliki kesatuan ide; kedua, tulisan itu harus mengandung kelengkapan; dan ketiga, tulisan itu harus memiliki kepaduan (Sutama, 2006). Ini berarti bahwa dalam sebuah tulisan harus ada sebuah ide sentral; ide ini ditunjang oleh uraian yang memadai; dan seluruh uraian itu disampaikan dalam bingkai struktur yang diidealkan. Pembahasan

hasil penelitian merupakan bagian skripsi yang sangat penting. Di sisi lain, Evans \& Gruba (2002:104) mengemukakan bahwa bagian pembahasan hasil penelitian merupakan bagian yang membuat mahasiswa paling khawatir. Alasannya adalah bahwa dalam menulis bagian ini, tension atau ketegangan antara bagian rasional dan bagian kreatif otak akan sangat jelas, karena harus membandingkan hasil penelitian dengan apa yang diduga berdasarkan teori yang ada untuk melihat ide atau pemikiran apa yang akan muncul.

Bagian pembahasan hasil penelitian secara esensial merupakan sintesis penelitian melalui penilaian professional dari peneliti. Sintesis mengintegrasikan masalah penelitian dan tinjauan pustaka dengan hasil penelitian. Penilaian professional dicerminkan dalam hakikat sintesis dan implikasi yang disarankan dalam bentuk simpulan dan rekomendasi (Sutama, 2006:64). Lebih lanjut ditegaskan oleh Suandi (2007) pembahasan merupakan bagian terpenting dari penelitian. Pada umumnya, kualitas suatu penelitian dapat dilihat dari bagian pembahasannya. Melalui bagian ini akan tampak sejauh mana penguasaan peneliti terhadap masalah yang ditelitinya dan cakrawala pengetahuannya. Demikian kompleksnya permasalahan pembahasan hasil penelitian, untuk itu diperlukan pedoman konsep tentang pembahasan suatu hasil penelitian.

Tujuan pembahasan adalah menyajikan interpretasi terhadap temuan, simpulan, dan rekomendasi bagi penelitian selanjutnya (Sutama, 2006:63). Penulis menggunakan bagian pembahasan untuk menjelaskan makna temuan dan menyampaikan kemungkinan implikasinya. Pembahasan lebih dari sekadar ringkasan penelitian. Dengan kalimat laian pembahasan bukanlah sekadar ringkasan hasil penelitian. Dwiloka dan Riana (2005:60) juga menegaskan, tujuan pembahasan adalah (1) menjawab masalah penelitian, atau menunjukkan bagaimana tujuan penelitian dicapai, (2) menapsirkan temuan penelitian, (3) mengintegrasikan temuan penelitian ke dalam kumpulan pengetahuan yang telah mapan, (4) memodifikasi teori yang ada atau menyusun teori baru, dan (5) menjelaskan implikasi lain dari hasil penelitian, termasuk keterbatasan penelitian.

Pembahasan merupakan evaluasi metodologi dan hasil penelitian untuk membantu pembaca memahami hasil penelitian dan bagaimana penggunaannya. Penulis memberikan penilaian terhadap hasil penelitian terkait dengan metode penelitian yang digunakan sehingga akan sekaligus tampak dalam pembahasan tersebut keungulan dan kekurangunggulan hasil yang diperoleh. Hal ini akan dapat 
memberikan gambaran kepada pembaca akan kekuatan hasil yang diperoleh. Semua ini akan memberikan gambaran sekaligus penyikapan bagi pembaca dalam memanfaatkan atau menggunakan hasil penelitian.

Pembahasan secara esensial merupakan sintesis penelitian melalui penilaian professional dari peneliti. Sintesis menintegrasikan masalah penelitian dan tinjauan pustaka dengan hasil penelitian. Penilaian professional peneliti dicerminkan dalam hakikat sintesis dan implikasi yang disarankan dalam bentuk simpulan dan rekomendasi.

Dalam penyajiannya masing penulis terjadi variasi dalam mengungkapkan isi dan organisasi bagian pembahasan. Beberapa peneliti memulainya dengan simpulan dan kemudian menganalisis simpulan itu, sementara peneliti lain akan menjelaskan mengapa mereka menemukan hasil itu, diikuti dengan keterbatasan penelitiaannya, baru kemudian mengemukakan simpulannya. Beberapa peneliti bisa jadi mengkombinasikan hasil dengan pembahasan dan simpulan.

Dalam penulisan skripsi, setelah menyajikan hasil penelitian diikuti dengan sub-bagian pembahasan hasil penelitian. Sub-bagian pembahasan merupakan suatu kesempatan unuk memaknai data secara lebih mendalam dan mengintegrasikan secara kreatif hasil-hasil penelitian dengan teori dan penelitian yang ada.

Meskipun ada petunjuk-petunjuk tentang penyajian Bab Metodologi dan Bab Hasil Penelitian, namun dalam hal isi dan format pembahasan hasil belum ada petunjuk-petunjuk formal. Sub-
Bagian Pembahasan yang baik berisi unsur-unsur berikut (Hartono, 2002 :116, Paltridge and Starfield, 2007:147). 1) Tinjauan tentang hasil-hasil penelitian yang penting, 2) Pertimbangan mengenai hasil-hasil penelitian ditinjau dari studi-studi penelitian yang ada, 3) Implikasi-implikasi mengenai studi tentang teori baru-baru ini (kecuali dalam studi-studi terapan yang murni), 4) Pengamatan yang cermat tentang hasil-hasil penelitian yang tidak berhasil mendukung atau hanya sebagai mendukung hipotesis-hipotesis anda), 5) Keterbatasan-keterbatasan penelitian yang mungkin mempengaruhi validitas atau penggenneralisasian hasil-hasil penelitian, 6) Saran-saran untuk penelitian lebih lanjut; dan 7) Implikasiimplikasi penelitian bagi bidang professional atau bidang-bidang terapan(boleh ada boleh tidak).

Sub-bagian Pembahasan merupakan latihan berpikir induktif, mengolah hasil-hasil spesifik penelitian dan menarik kesimpulan kedalam dunia teori dengan menghubungkan hasil-hasil penelitian yang ditemukan dengan kepustakaan yang ada. Di sini dikemukakan argumentasi konseptual berdasarkan data yang diperoleh, memahami makna data dari hubunganhubungan yang telah muncul di antara variable-variabel penelitian. Jadi, dilakukan evaluasi sejauh mana penelitian menjawab pertanyaanpertanyaan yang dirumuskan dalam penelitian berdasarkan penalaran sebanyak mungkin pada data itu sendiri. Dalam mengemukakan interpretasiinterpretasi tentang hasil-hasil penemuan, pertimbangkanlah keunggulan dan kelemahan interpretasiinterpretasi lainnya dari kepustakaan, 
dan kesesuaian serta ketidaksesuaian antara data-data dengan kesimpulankesimpulan dalam hubungannya dengan sumbangan (kontribusi) dari pihak lain. Dengan demikian sub-bagian Pembahasan secara terbuka menginformasikan dan mengevaluasi penjelasan-penjelasan hasil-hasil penelitian.

Dalam pembahasan tidaklah cukup untuk mengungkapkan kembali hasil-hasil penelitian. Walaupun bab ini merupakan bagian yang baik untuk memulai. Salah satu cara terbaik untuk memulai bab ini adalah meninjau status masing-masing hipotesis dan pertanyaan-pertanyaan penelitian. Tetaplah berfokus pada penjelasan secara langsung mengenai apa yang ditentukan, dengan mengambil gagasan-gagasan yang penting saja. Pembahasan yang baik memadukan masing-masing hasil penelitian dalam konteks teoritis yang disajikan dalam kajian kepustakaan. Dengan demikian perlu menyitir beberapa penelitian terkait yang dibahas sebelumnya, serta kembali ke kajian kepustakaan untuk menemukan cara-cara lain dalam memahami hasil-hasil penelitian dan mencari bukti bukti yang menguatkan atau melemahkan.

Terkait dengan interpretasi hasil penelitian dalam bagian pembahasan, Sutama (2006:64-69) mengemukakan bahwa begitu hasil penelitian disajikan, selanjutnya perlu dilakukan analisis dan interpretasi. Analisis ini merupakan spekulasi rasional untuk menjawab beberapa pertanyaan berikut. Mengapa hasil penelitian seperti itu? Apa yang mungkin mempengaruhi hasil penelitian? Adakah keterbatasan yang perlu mendapat perhatian? Seberapa jauh hipotesis mendapat dukungan? Apa makna dari temuan penelitian itu? Bagaimana kaitan hasil penelitian dengan temuan penelitian sebelumnya? Semua pertanyaan tersebut dapat digunakan sebagai pemandu dalam membahas dan menginterpretasikan hasil penelitian. Interpretasi terhadap hasil penelitian mungkin berkaitan dengan masalah dan/ atau hipotesis penelitian, metode penelitian, dan penelitian sejenis sebelumnya. Lebih lanjut dipaparkan oleh sutama (2006) interpretasi dapat dilakukan terhadap hal-hal yang terkait seperti: Interpretasi yang berkaitan dengan masalah dan/atau hipotesis, Interpretasi yang berkaitan dengan metodologi, (3) Interpretasi yang berkaitan dengan pemilihan subjek, (4) Interpretasi yang berkaitan dengan pengukuran variable, (5) Interpretasi yang berkaitan dengan perlakukan dalam eksperimen, (6) Interpretasi yang didasarkan pada prosedur statistic, dan (7) Interpretasi yang berkaitan dengan penelitian sebelumnya.

Dalam sub-bagian Pembahasan, ada beberapa kesalahan umum yang sering ditemukan. Untuk menghindari terjadinya kesalahan tersebut ada beberapa hal yang perlu diperhatikan dan diwaspadai (Glatthom dan Joyner,2005, Rudestam dan Newton,1992). Sebagai berikut. (1) Analisis data harus sudah dipaparkan secara sistematis pada bab hasil analisis data dan temuan penelitian tidak dibahas dalam sub-bagian pembahasan. (2) Jangan mengulang dan merumuskan kembali hal-hal yang telah ditulis. Bab ini atau bagian ini bisanya dianggap sebagai ringkasan dari temuan khusus. Dalam bab ini, 
daripada mendeskripsikan temuan lagi, lebih baik membahas temuan. (3) Kecenderungan umum di kalangan mahasiswa adalah menyajikan semua kritikan yang ada terhadap penelitian dan melakukan hal yang demikian dengan gaya memaafkan. Sebaiknya terimalah penelitian itu apa adanya. Kalau ada kritik yang mendasar, seperti adanya temuan yang negatif karena kesalahan dalam desain penelitian, maka ada baiknya menanyakan mengapa penelitian tersebut dulunya dilakukan. Tidak masuk akal kalau penulis menuliskan kelemahan penelitian yang tidak disengaja atau yang merupakan kelemahan dalam penelitian. Andaikata ada kelemahan penelitian yang disebutkan maka harus ditulis pula kelebihan penelitian atau beberapa cara mengatasi kelemahan itu. (4) Jangan menawarkan rekomendasi yang panjang dan banyak untuk penelitian selanjutnya. Sebaiknya saran atau rekomendasi dipusatkan pada satu atau dua hal yang paling utama. Saran atau rekomendasi yang diberikan sebaiknya hanya yang berkaitan dengan apa yang ditemukan oleh peneliti sebagai suatu yang perlu dilakukan (Joyner,2005). (5) Jangan menganjurkan penelitian yang akan datang yang sebenarnya dengan mudah dapat dilakukan dalam penelitian yang sedang dilakukan ini. Ini hanya menunjukkan bahwa peneliti belum melakukan pekerjaan yang cermat dalam menganalisis data peneliti sendiri. (6) Jangan memasukkan uraianuraian rinci yang tidak berarti atau memberikan ulasan tentang suatu topik tanpa tujuan yang jelas. Pembahasan harus logis dan terfokus.
Berdasarkan pemikiran di atas, perlu segera dikaji pembahasan hasil penelitian dalam skripsi mahasiswa. Berdasarkan uraian dalam bagian latar belakang di atas, dirumuskan masalah sebagai berikut. (1) Bagaimanakah keberadaan unsur-unsur bagian pembahasan hasil penelitian dalam skripsi mahasiswa Jurusan Pendidikan Bahasa dan Sastra Indonesia? (2) Unsur- unsur apa sajakah yang luput pada penulisan pembahasan hasil penelitian dalam skripsi mahasiswa Jurusan Pendidikan Bahasa dan Sastra Indonesia?

Sejalan dengan rumusan masalah di atas, penelitian ini dilaksanakan bertujuan untuk mencapai tujuan berikut. (1) Mengetahui keberadaan unsur-unsur bagian pembahasan hasil penelitian dalam skripsi mahasiswa Jurusan Pendidikan Bahasa dan Sastra Indonesia. (2) Mengetahui unsur-unsur yang luput pada penulisan pembahasan hasil penelitian dalam skripsi mahasiswa Jurusan Pendidikan Bahasa dan Sastra Indonesia.

Ada dua manfaat yang dapat diperoleh dari penelitian ini. Yang pertama adalah manfaat teoretis dalam betuk memberikan kontribusi terhadap perkembangan teori wacana tulis, khususnya wacana tulis ilmiah. Yang kedua adalah manfaat praktis dalam bentuk memberikan masukan kepada dosen pembimbing dalam proses bimbingan skripsi dalam rangka meningkatkan mutu tulisan ilmiah mahasiswa. Bagi dosen pengampu mata kuliah penulisan karya ilmiah dapat mengintensifkan pelatihan yang diberikan kepada mahasiswa terfokus pada permasalahan yang ada sehingga 
mahasiswa dapat meningkatkan kualitas penulisan skripsinya. Bagi mahasiswa, dapat lebih meningkatkan mutu tulisan karya ilmiah yang dibuatnya.

Subjek penelitian adalah pembahasan hasil penelitian dalam skripsi mahasiswa Jurusan Bahasa dan Sastra Indonesia tahun terakhir. Sedangkan objek penelitianya terkait permasalahan dalam penelitian ini yakni keberadaan unsur-unsur pembahasan hasil penelitian dan unsur-unsur yang luput dari penulisa bagian pembahasan. Pada setiap tahunnya diadakan enam kali periode ujian skripsi. Setiap periode rerata peserta ujian sekitar delapan skripsi. Dengan mempertimbangkan representativitas dan waktu penelitian yang ada, dari masing-masing periode akan diambil tiga skripsi secara ramdom. Dengan demikian dalam penelitian ini akan dikaji delapan belas pembahasan hasil dalam skripsi.

\section{HASIL PENELITIAN}

Setelah dianalisis secara menyeluruh bagian pembahasan pada skripsi mahasiswa perunsur yang ada muncul dalam pembahasan, dapat disampaikan dalam tabel berikut

Tabel 1 Keberadaan Unsur-Unsur Pembahasan Hasil Penelitian Pada Skripsi Mahasiswa

\begin{tabular}{|c|l|l|l|l|l|c|}
\hline $\begin{array}{l}\text { Skrip } \\
\text { si }\end{array}$ & $\begin{array}{l}\text { Tinjauan } \\
\text { Tentang } \\
\text { Hasil-Hasil } \\
\text { Penelitian } \\
\text { Yang } \\
\text { Penting }\end{array}$ & $\begin{array}{l}\text { Pencermata } \\
\text { n Terhadap } \\
\text { Hasil Yang } \\
\text { Mendukung/ } \\
\text { Tidak } \\
\text { Hipotesis }\end{array}$ & $\begin{array}{l}\text { Pertimbanga } \\
\text { Penelitian } \\
\text { Ditinjau Daril } \\
\text { Penelitian } \\
\text { Yang Ada }\end{array}$ & $\begin{array}{l}\text { Implikasi } \\
\text { Mengenai } \\
\text { Studi } \\
\text { Tentang } \\
\text { Teori } \\
\text { Terbaru }\end{array}$ & $\begin{array}{l}\text { Keterbatasa } \\
\text { n Penelitian } \\
\text { YangMempe } \\
\text { ngaruhi } \\
\text { Generalisasi/ } \\
\text { Hasil } \\
\text { Penelitian }\end{array}$ & $\begin{array}{l}\text { Saran- } \\
\text { Saran } \\
\text { Untuk } \\
\text { Penelitia } \\
\text { Lebih } \\
\text { Lanjut }\end{array}$ \\
\hline 1 & 2 & 3 & 4 & 5 & 6 & 7 \\
\hline 01 & Ada & Ada & Ada & Ada & Tidak & Ada \\
\hline 02 & Ada & Ada & Ada & Ada & Tidak & Ada \\
\hline 03 & Ada & Ada & Tidak & Ada & Tidak & Tidak \\
\hline 04 & Ada & Ada & Tidak & Ada & Tidak & Ada \\
\hline 05 & Ada & Ada & Ada & Ada & Tidak & Ada \\
\hline 06 & Ada & Ada & Ada & Ada & Tidak & Ada \\
\hline 07 & Ada & Ada & Ada & Ada & Tidak & Tidak \\
\hline 08 & Ada & Ada & Ada & Ada & Tidak & Ada \\
\hline 09 & Ada & Ada & Tidak & Ada & Tidak & Ada \\
\hline 10 & Ada & Ada & Tidak & Ada & Tidak & Ada \\
\hline 11 & Ada & Ada & Ada & Ada & Tidak & Ada \\
\hline 12 & Ada & Ada & Ada & Ada & Tidak & Ada \\
\hline 13 & Ada & Ada & Tidak & Ada & Tidak & Ada \\
\hline 14 & Ada & Ada & Ada & Ada & Tidak & Ada \\
\hline
\end{tabular}




\begin{tabular}{|c|c|c|c|c|c|c|}
\hline 15 & Ada & Ada & Ada & Ada & Tidak & Tidak \\
\hline 16 & Ada & Ada & Ada & Ada & Tidak & Ada \\
\hline 17 & Ada & Ada & Tidak & Ada & Tidak & Ada \\
\hline 18 & Ada & Ada & Tidak & Ada & Tidak & Ada \\
\hline $\begin{array}{c}\text { Pers } \\
\text { entas } \\
\text { e } \\
\text { yang } \\
\text { ada }\end{array}$ & $\mathbf{1 8 ( 1 0 0 \% )}$ & $\mathbf{1 8 ( 1 0 0 \% )}$ & $\mathbf{1 1 ( 6 1 \% )}$ & $\mathbf{1 8 ( 1 0 0 \% )}$ & $\mathbf{0}(\mathbf{0} \%)$ & $\mathbf{1 5}$ \\
\hline $\begin{array}{c}\text { Pers } \\
\text { entas } \\
\text { e } \\
\text { yang } \\
\text { luput }\end{array}$ & $\mathbf{0 ~ ( 0 \% )}$ & $\mathbf{0 ( 0 \% )}$ & $\mathbf{7 ( 3 9 \% )}$ & $\mathbf{0 ( 0 \% )}$ & $\mathbf{1 8 ( 1 0 0 \% )}$ & $\mathbf{3}(\mathbf{1 7 \%})$ \\
\hline
\end{tabular}

Dari tabel tersebut tampak bahwa skripsi yang bagian pembahasan hasil yang benar-benar lengkap sesuai dengan tuntutan keseluruhan unsur yang harus ada pada bagian pembahasan hasil tidak ada atau jumlahnya $0 \%$. Ini berarti tidak ada skripsi masiswa yang lengkap kandungan unsur pembahasan hasilnya. Dengan kalimat lain tidak ada skripsi mahasiswa yang lengkap unsur-unsur pembahasan hasil penelitiannya.Kalau ditinjau dari keeberadaan perunsur, karena enam unsur yang dituntut dan hanya lima unsur yang ada, kalau dipersentasekan tingkat presentase keberadaan unsurnya 83\%.

Sedangkan kalau ditinjau dari keberadaan perunsur pembahasan hasil penelitian, dari 18 skripsi yang dianalisis ditemukan bahwa unsur yang lengkap keberadaannya adalah: unsur tinjauan tentang hasil-hasil penelitian yang penting $100 \%$, pencermatan terhadap hasil yang mendukung/tidak hipótesis $100 \%$, implikasi mengenai studi tentang teori terbaru $100 \%$, saran-saran untuk penelitian lebih lanjut sejumlah $83 \%$, pertimbangan hasil penelitian ditinjau dari penelitian yang telah ada $61 \%$, sedangkan unsur keterbatasan penelitian yang mempengaruhi generalisasi/hasil penelitian tidak ada sama sekali atau $0 \%$.

Jadi unsur yang luput sama sekali adalah satu unsur yaitu unsurketerbatasan penelitian yang mempengaruhi generalisasi. Karena hanya satu unsur yang luput, kalau dipersentasekan tingkat keluputannya adalah $17 \%$.

Jadi dapat ditegaskan bahwa keberadaan unsur-unsur pembahasan hasil penelitian pada skripsi mahasiswa S1 Jurusan Pendidikan Bahasa dan Sastra Indonesia tidak ada yang lengkap. Unsur yang luput sama sekali dalam pembahasan hasil penelitian adalah unsur keterbatasan penelitian yang mempengaruhi generalisasi/hasil penelitian. Kalau dirinci bila ditinjau dari keberadaan perunsur persentasenya sebagai berikut: (1) tinjauan tentang hasil-hasil penelitian yang penting sejumlah $100 \%$, (2) pencermatan terhadap hasil yang mendukung/tidak hipótesis sejumlah 100\%, (3) Implikasi mengenai studi tentang teori terbaru 
sejumlah 100\%, (4) Saran-saran untuk penelitian lebih lanjut 83\%, (5) pertimbangan hasil penelitian ditinjau dari penelitian yang ada sejumlah $61 \%$, dan (6) keterbatasan penelitian yang mempengaruhi generalisasi/hasil penelitian sejumlah $0 \%$.

Dari keberadaan unsur-unsur tersebut di atas akan dapat dirinci persentase unsur-unsur yang luput dari bagian pembahasan yaitu: keterbatasan penelitian yang mempengaruhi generalisasi/hasil penelitian luput total $(100 \%)$ atau tidak ada sama sekali, (2) pertimbangan hasil penelitian ditinjau dari penelitian yang ada, luput 39\%, dan (3) saran-saran untuk penelitian lebih lanjut, luput $17 \%$.

\section{PEMBAHASAN HASIL}

Sebagian mahasiswa mengalami hambatan dalam menyelesaikan studi disebabkan oleh menulis penelitian berupa skripsi sebagai tugas akhir. Mahasiswa mengeluh seakan-akan mereka menyerah sebelum bertempur. Upaya bimbingan terhadap mahasiswa dan sasaran bimbingan oleh dosen pembimbing perlu agar terfokus pada permasalahan yang ada yang dihadapi mahasiswa. Bagian pembahasan hasil penelitian merupakan bagian yang membuat mahasiswa paling khawatir. Dalam menulis bagian ini, tensión atau ketegangan antara bagian rasional dan bagian kreatif otak akan sangat jelas, karena harus membandingkan hasil penelitian dengan apa yang diduga berdasarkan teori yang ada untuk melihat idea tau pemikiran apa yang muncul (Evans \& Gruba, 2002). Mahasiswa sering kurang cermat dan kurang komprehensif dalam menyelesaikan bagian pembahasan hasil. Sehingga berpengaruh pada kualitas skripsi mahasiswa (Hartono,2002:116). Pada hal bagian pembahasan hasil merupakan bagian yang terpenting dari penelitian (Suandi,2007). Karena keterbatasan waktu dosen pembimbing, ketidaktahuan mahasiswa dan berbagai faktor lainnya kelengkapan unsur pembahasan banyak yang luput dari perhatian, untuk itu perlu dikaji keberadaan unsur bagian pembahasan sripsi mahasiswa dan unsur-unsur apa saja yang luput dari penulisan bagian pembahasan hasil.

Berdasarkan hasil penelitian ini dikemukakan dan dibahas temuan penelitian yang penting yaitu: (1) Keberadaan unsur-unsur bagian pembahasan hasil penelitian skripsi mahasiswa, (2) Unsur-unsur pembahasan hasil yang luput pada skripsi mahasiswa. Adapun rinciannya sebagai berikut. (1) Tinjauan tentang hasil-hasil penelitian yang penting sejumlah 100\%,(2) Pencermatan terhadap hasil yang mendukung/tidak hipótesis sejumlah 100\%, (3) Implikasi mengenai studi tentang teori terbaru sejumlah $100 \%$, (4) Saran-saran untuk penelitian lebih lanjut 83\%, (5) Pertimbangan hasil penelitian ditinjau dari penelitian yang ada sejumlah $61 \%$, dan (6) Keterbatasan penelitian yang mempengaruhi generalisasi/hasil penelitian sejumlah $0 \%$.

Kalau dicermati keberadaan unsur yang ada dari persentase yang ada tampak dari 6 unsur yang harus ada ternyata 5 unsur $(=83 \%)$ telah memenuhi keberadaan unsur-unsur pembahasan hasil penelitian. Dengan kalimat lain, keberadaan unsur-unsur 
bagian pembahasan hasil penelitian mahasiswa telah mencapai 83\%. Adapun unsur yang ada meliputi unsur: tinjauan tentang hasil-hasil penelitian yang penting, pencermatan terhadap hasil yang mendukung/tidak hipótesis, implikasi mengenai studi tentang teori terbaru, saran-saran untuk penelitian lebih lanjut, dan pertimbangan hasil penelitian ditinjau dari penelitian yang ada.

Unsur tinjauan tentang hasil penelitian yang penting tampak 100\% artinya mahasiswa telah melakukan tinjauan terhadap hasil-hasil yang penting. Hal ini diungkapkan dengan berbagai model. Ada yang mengemukakan secara deduktif ada yang mengemukakan secara induktif dan mengkombinasikan keduanya. Secara deduktif yaitu dikemukan pada awal simpulan secara umum atau secara menyeluruh barulah diikuti dengan pembahasan secara rinci satu persatu. Sedangkan secara induktif penulis langsung mengemukakan satu persatu tinjauan hasilnya dan langsung membahasnya. Hal ini senada dengan apa yang dikemukakan oleh Sutama (2006) bahwa dalam penyajiannya masing-masing penulis terjadi variasi dalam pengungkapan isi dan organisasi dalam pembahasan. Beberapa peneliti memulainya dengan simpulan dan kemudian menganalisis simpulan itu, sementara peneliti lain akan menjelaskan mengapa mereka menemukan hasil itu diikuti dengan keterbatasan penelitiannya baru mengemukakan simpulan. Beberapa peneliti bisa jadi mengkombinasikannya.

Unsur pencermatan terhadap hasil yang mendukung/tidak hipótesis, tampak $100 \%$ artinya mahasiswa telah melakukan pengamatan dan pencermatan terhadap hasil yany mendukung/tidak hipótesis. Hal ini telah sejalan dengan petunjuk pembahasan hasil penelitian yaitu pengamatan yang cermat tentang hasil-hasil penelitian yang berhasil dan tidak berhasil mendukung hipótesis (Paltridge and Starfield, 2007:147; Hartono, 2002,116). Dalam melakukan pencermatan ini masih banyak uraiannya tergelincir pada pengungkapan kembali hasil penelitiannya sehing terkesan hanya mengulang dari bagian penyajian hasil. Pencermatan yang dilakukan belum terfokus pada bagian-bagian terpenting dari temuan ke arah menjawab masalah yang telah dirumuskan. Sehingga pembahasannya terkesan panjang namun masih banyak ada isi uraian hanyalah mengulang bagian penyajian hasil penelitian. Di sini mahasiswa dituntut memfokuskan atau memilih data-data yang penting yang dimanfaatkan untuk menjawab hipótesis ataupun permasalahan yang dikemukakan.

Hal ini telah ditegaskan oleh Hartono (2002;117) tidaklah cukup untuk mengungkapkan kembali hasilhasil penelitian anda, walaupun bab ni merupakan bagian yang baik untuk memulai. Salah satu cara terbaik untuk memulai babi ni adalah meninjau status masing-masing hipotesis dan pertanyaan-pertanyaan penelitian bilamana data-data telah dikumpulkan dan dianalisis. Tetaplah berfokus pada penjelasan secara langsung mengenai apa yang anda tentukan, dengan mengambil gagasan-gagasan yang penting saja. Hal ini sejalan dengan apa telah ditemukan terkait dengan kesalahan umum dalam menulis bab 
pembahasan. Telah dingatkan oleh para pakar bahwa dalam menulis bab pembahasan jangan mengulang pernyataan yang telah dikatakan. Bab ni atau bagian ini biasanya dianggap sebagai ringkasan dari temuan khusus. Dalam bab ini, dari pada mendeskripsikan temuan lagi, lebih baik membahas temuan. Lebih jauh ditegaskan bahwa jangan memasukkan hal-hal yang kurang perlu berkaitan dengan topik penelitian. Bab ni merupakan bab tempat pemikiran kreatif. Tetapi seperti bab-bab lainnya dalam tesis atau disertasi, bab inipun harus logis dan terfokus) (Rudestam dan Newton, 2001; Glatthorn \& Joyner, 2009 dalam Emelia,2009). Untuk itu dalam melakukan pembahasan seorang penulis perlu kontrol diri dan memusatkan atau memfokuskan perhatiannya pada temuan penelitiaanya yang penting-penting saja.

Unsur implikasi mengenai studi tentang teori terbaru keberadaannya sejumlah $100 \%$, artinya ditinjau dari keberadaannya seluruh skripsi mahasiswa telah melakukannya dalam pembahasanya. Hal ini telah sesuai dengan petunjuk pembahasan hasil yaitu implikasi-implikasi mengenai studi tentang teori baru-baru ini kecuali dalam studi-studi terapan murni (Paltridge and Starfield, 2007:147; Hartono,2002,116). Dalam pembahasan yang dilakukan teori-teori yang digunakan cenderung kurang mutakhir dan tidak diperoleh dari sumber aslinya. Artinya sumber yang digunakan dari pustaka-pustaka yang agak lama tahunnya dari penelitian yang sedang dilakukan dan diambil dari sumber hasil petikan dari penulis lain. Hal ini tentu saja perlu dihindari karena sumber-sumber yang harus digunakan dalam penulisan karya ilmiah dituntut mutakhir dan relevan. Bisa jadi ini ditoleransi oleh pembimbing dengan dasar pemikiran bahwa mahasiswa dalam menulis karya ilmiah ini adalah dalam rangka membelajarkan mahasiswa sehingga yang dipentingkan adalah prosesnya yakni siswa bisa membuat karya ilmiah. Hal ini tentu saja tidak bisa dibiarkan secara terus menerus dan perlu secara bertahap mahasiswa dibimbing dan diingatkan serta diimbau menggunakan pustaka sebagaimana mestinya sesuai dengan ketentuan.

Unsur saran-saran untuk penelitian lebih lanjut keberadaaannya $83 \%$, artinya telah ada saran-saran untuk penelitian lanjut yang persentasenya tergolong tinggi. Hal ini telah sejalan dengan petunjuk pembuatan bab pembahasan yaitu mengemukakan saran-saran untuk penelitian lebih lanjut (Paltridge and Starfield, 2007:147; Hartono, 2002,116). Tujuan pembahasan adalah menyajikan interpretasi terhadap temuan, simpulan dan rekomendasi bagi penelitian selanjutnya (Sutama, 2006:63). Lebih lanjut ditegaskan bahwa pembahasan atau penilaian profesional peneliti dicerminkan dalam hakikat síntesis dan implikasi yang disarankan dalam bentuk simpulan dan rekomendasi. Dalam penyajian saran-saran yang disampaikan mahasiswa cenderung penyajiannya sangat umum dan cenderung sama polanya sama yaitu; "Peneliti lain hendaknya melakukan penelitian lebih lanjut dan dapat menggunakan penelitian ini sebagai pedoman". Dengan demikian tidak jelas, penelitian lebih lanjut tentang apa? Selanjutnya bagian mananya yang perlu 
dilanjutkan yang dipandang penting dan belum tuntas. Terkesan saran-saran penelitian lanjut yang disampaikan tidak jelas, kurang rinci dan tidak pasti. Saran yang dibuat atau dirumuskan selalu bersumber pada temuan penelitian, pembahasan dan simpulan hasil penelitian. Saran yang baik rumusannya bersifat rinci, spesifik dan operasional. Artinya, pihak yang disarankan, jika hendak melaksanakan saran tersebut, tidak mengalami kesulitan dalam menapsirkan atau mengaplikasikan (Wendra, 2010:45). Bagian mana atau tahap mana yang perlu diteruskan penelitiaannya sesuai dengan hasil kajian yang telah dibahas pada penelitian tersebut. Rudestam \& Newton (2001) menegaskan saran penelitian lanjut untuk menyarankan penelitian yang melangkah satu tahap ke depan dari penelitian yang dilakukan. Glatthorn dan Joyner (dalam Emelia, 2009;222) menyarankan bahwa rekomendasi yang diberikan hanya yang berkaitan dengan apa yang ditemukan oleh penelitian yang dilaporkan sebagai sesuatu yang perlu dilakukan.

Unsur pertimbangan hasil penelitian ditinjau dari penelitian yang ada keberadaannya $61 \%$, artinya telah hada pada bagian pembahasan skripsi mahasiswa. Hal inipun telah sesuai dengan petunjuk membuat bagian pembahasan hasil penelitian yaitu adanya unsur pertimbangan hasil penelitian ditinjau dari penelitian yang ada (Paltridge and Starfield, 2007:147; Hartono, 2002,116). Dilihat dari keberadaan presentasenya baru pada tahap memenuhi syarat minimal atau sebatas cukup. Ini berati masih banyak mahasiswa mengalami kesulitan dalam bab ini yaitu melakukan pembahasan dengan menggunakan pertimbangan hasil penelitian ditinjau dari penelitian yang ada. Temuan ini sejalan dengan temuan hasil penelitian yang dilakukan oleh Emelia. E tahun 2008 dalam menganalisis tesis yang ditulis dalam bahasa Inggris oleh mahasiswa Program Magister di Program Studi Pendidikan Bahasa Inggris Universitas Pendidikan Indonesia, ditemukan bahwa penulis gagal untuk kembali kepada kajian pustaka yang telah ditulis dalam Bab Dua atau dalam literatura review untuk mengintegrasikan hasil penelitian dengan penelititian empiris lain yang meneliti fenomena yang sama. Dengan demikian, dalam pembahasan ini, penulis perlu mengutip penelitian yang relevan yang dibahas sebelumnya, dan kembali ke kajian pustaka untuk memahami lebih baik temuan penelitian dan mencari bukti yang mengonfirmasi atau yang bertentangan dengan data atau hasil penelitian yang ada. Ini juga sekaligus indikator akan keterbatasan mahasiswa membaca jurnal-jurnal hasil penelitian terkait dan mencerminkan peneliti belum mengikuti secara intensif akan perkembangan permasalahan penelitian yang sedang dikaji. Apabila hal ini telah dilakukan peneliti dalam pembahasannya akan memperlihatkan kepada pembaca bagaimana penelitian memperkokoh dasar pengetahuannya (Glattorn \& Joyner,2005:208). Betapun kesulitan yang dialami mahasiswa, pembahasan yang mengaitkan dengan penelitian yang telah ada harus dilakukan. Hal ini telah ditegaskan oleh para pakar bahwa temuan penelitian harus dibahas dan salah satu tahap dalam membahas penelitian adalah menghubungkan atau mengintegrasikan temuan penelitian dan membahasnya 
berkaitan dengan penelitian sebelumnya (Rudestam \& Newton,2001; Thomas,2000; Barras,2002; Glattorn \&Joyner,2005; Paltridge \& Stairfield, 2007).

Unsur keterbatasan penelitian yang mempengaruhi generalisasi/hasil penelitian ada $0 \%$. Artinya unsur ini tidak ada sama sekali atau luput dari perhatian mahasiswa. Karena hanya satu unsur yang luput dari enam unsur yang harus ada dalam pembahasan, itu berarti dilihat dari segi keberadaan besarnya presentase yang luput dari unsur pembahasan hasil penelitian adalah sebesar 17\%. Satu aspek penting dari bagian pembahasan adalah menunjukkan keterbatasan penelitian, yakni faktor-faktor atau variabel-variabel yang perlu dipertimbangkan di dalam memanfaatkan penelitian itu. Peneliti akan menunjukkan bahwa hasil penelitian atau simpulan yang ditarik terbatas untuk subjek dengan karakteristik tertentu, rancangan atau latar tertentu (Sutama, 2006:69; Hartono,2002). Luputnya unsur keterbatasan penelitian yang mempengaruhi generalisasi/hasil penelitian disebabkan oleh arti kata keterbatasan yang dipahami oleh mahasiswa yang identik dengan kelemahan. Kalau menyampaikan keterbatasan sama dengan menyampaikan kelemahan penelitian sendiri. Akibat pemahaman sempit tersebut menyebabkan mahasiswa cenderung menghindar dalam mengemukakan keterbatasan penelitiannya. Pada kenyataannya mengemukakan keterbatasan akan memberikan pemahaman akan makna penelitian atau makna generalisasi yang dihasilkan. Hal ini akan menuntun pihak- pihak yang ingin memetik manfaat dari hasil penelitian tersebut dapat bersikap dengan jelas dan pasti terhadap hasil penelitian tersebut. Oleh karena itu syarat seorang ilmuwan dituntut memiliki sifat-sifat jujur, terbuka, teliti, kritis (Wendra, 2010;1).

Terkait dengan keterbatasan, penelitian ini mempunyai keterbatasan yaitu subjek penelitian ini hanya terbatas pada skripsi mahasiswa Jurusan Pendidikan Bahasa dan Sastra Indonesia yang jumlahnya hanya sebagian kecil dari mahasiswa yang ada di Fakultas Bahasa dan Seni. Demikian halnya aspek yang dibahas sebatas pada bagian pembahasan dari bagianbagian yang ada pada skripsi yang masih bermasalah dalam penulisannya di kalangan mahasiswa. Untuk itu, sangatlah tepat kalau peneliti lain melakukan penelitian lanjutan pada jangkauan subjek yang lebih luas yakni jurusan yang ada di Fakultas Bahasa dan Seni dan pada aspek lain dari skripsi yang masih bermasalah di kalangan mahasiswa.

\section{PENUTUP}

Dari hasil penelitian dan pembahasan terhadap enam unsurunsur bagian pembahasan pada skripsi mahasiswa dapat disimpulkan keberadaan unsur-unsur pembahasan hasil penelitian pada skripsi mahasiswa S1 Jurusan Pendidikan Bahasa dan Sastra Indonesia tidak ada yang lengkap dengan persentase kelengkapan 83\%. Unsur yang luput sama sekali dalam pembahasan hasil penelitian adalah unsur keterbatasan penelitian yang mempengaruhi generalisasi/hasil penelitian dengan persentase $17 \%$. Kalau dirinci bila 
ditinjau dari keberadaan perunsurnya sebagai berikut: (1) tinjauan tentang hasil-hasil penelitian yang penting sejumlah $100 \%$,(2)unsur pencermatan terhadap hasil yang mendukung/tidak hipótesis sejumlah 100\%, (3) Implikasi mengenai studi tentang teori terbaru sejumlah $100 \%$, (4) Saran-saran untuk penelitian lebih lanjut 83\%, (5) pertimbangan hasil penelitian ditinjau dari penelitian yang ada sejumlah $61 \%$, dan (6) keterbatasan penelitian yang mempengaruhi generalisasi/hasil penelitian sejumlah $0 \%$. Walaupun persentase kelengkapan unsur-unsur tergolong tinggi itu terbatas pada tinjauan keberadaannya atau ada tidaknya unsur-unsur. Namun dari segi kualitas penyajian pembahasan masing-masing unsur masih perlu ditingkatkan kualitasnya.

\section{DAFTAR PUSTAKA}

Arifin. 2006. Penulisan Karya IImiah dengan Bahasa yang Benar. Jakarta: Mediyatama Sarana Perkasa.

Dwiloka. B. dan Riana. R. 2005. Teknik Menulis Karya IImiah. Jakarta: PT. Rineka

Cipta.

Emelia. E. 2009. Menulis Tesis dan Desertasi. Bandung: Alfabeta

Hartono. 2002. Bagaimana Menulis Tesis. Malang: Universitas Muhammadiyah

Malang.

Lincoln, Y.S. \& Guba, E. G. 1985. Naturallistic Inquiry. New Delhi. Sage Publication
Patridge. B.\& Starfield.S. 2007. Thesis and Dissertation Writing in a Second Language. A Handbook for Supervisors. London: Routledge.

Rudestam, K.F. and Newton, R:R. 2001. Surviving Your Disertation: $A$. Comprehensive Guide to Content and Process. Newbury Park, CA: Sage.

Sutama. I. Made..2003. Pendahuluan Artikel IImiah dalam Jurnal Media Komunikasi FPIPS IKIP Negeri Singaraja (Laporan penelitian tidak diterbitkan).

Sutama, I Made. 2006. Metodologi Penelitian Pendidikan. Singaraja: Undiksha.

Suandi I. N. \& Sutama I. I Made. 2007. Penulisan Karya IImiah (Materi Pendidikan dan Pelatihan Profesi Guru). Singaraja: Undiksha.

Wendra. I. Wayan. \& Putrayasa I.B. 2006. Penggunaan Media Skripsi dalam Penerapan Pembelajaran Berbasis Inkuiri untuk Meningkatkan Kemampuan Mahasiswa Menulis Karya IImiah (Laporan penelitian tidak diterbitkan).

Wendra. I Wayan. 2010. Penulisan Karya IImiah (buku ajar). Singaraja: Undiksha.

Wibowo, Wahyu. 2008. Piawai Menembus Jurnal Terakriditasi Paradigma Baru Kiat Menulis Artikel IImiah. Jakarta: Bumi Aksara.

Jurnal Pendidikan Indonesia | 424 